\title{
A STUDY ON ANTIOXIDANT PROPERTIES OF DIFFERENT BIOACTIVE COMPOUNDS
}

\author{
Ghosh Rajat*, Deb Panchali \\ Department of Pharmacy, Tripura University (A Central University), Suryamaninagar, Tripura-799022, India
}

*Corresponding Author's E-mail: rajatghosh@tripurauniv.in

\begin{abstract}
Free radicals induce damage mainly to biomembranes and DNA due to peroxidation, which lead to tissue damage resulting in number of degenerative diseases. Antioxidants can neutralise the effect of these free radicals through various ways and may protect the body from harmful alterations. Antioxidants may be of different types viz. enzymatic, non-enzymatic and also found from plant sources. Nowadays, numerous synthetic antioxidant supplements are also found in the market. The antioxidative potential of samples can be assayed by different in vitro and in vivo methods. The present review describes a brief account of the free radical generation, their role in aging and other diseases, classification of antioxidants, their $n$ atural and synthetic sources, possible mechanism and several assay methods of free radical scavenging activity of different bioactive compounds.
\end{abstract}

Keywords: Antioxidants, DPPH, Free radicals, Oxidative stress, Reactive oxygen species.

\section{INTRODUCTION}

An antioxidant is a chemical that reduces the rate of particular oxidation reactions in a specific context ${ }^{1}$. Vitamin $\mathrm{C}$ and Vitamin $\mathrm{E}$ were the first recognized antioxidants, but other substances that have powerful antioxidant properties have also been recognized such as: Selenium, Carotenoids (Beta-carotene, Lutein, Lycopene, Sulforaphane, Zeaxanthin, and Astaxanthin), Bioflavonoids (Anthocyanins, Proanthocyanidins, Quercetin, and Apigenin), Coenzymes, Soy Isoflavones (Genistein and Daidzein), and many less well-known compounds found in fruits and vegetables ${ }^{2}$.

Free radicals are atoms or groups of atoms with unpaired electrons and can be formed when oxygen interacts with certain molecules. Free radicals are highly reactive, that's why they can start a chain reaction immediately once they are formed. They have the capability to damage cellular components such as DNA and the cell membranes when they react. The formation of free radicals can be happened during normal metabolic functions or introduced from the environment ${ }^{3}$. Free radicals are inherently unstable, since they contain extra energy. To reduce their energy load, free radicals react with certain chemicals in the body, and in the process, interfere with the cells' ability to function normally. Free radicals are believed to play a major role in different health conditions, including the aging process, cancer, atherosclerosis, Parkinson's disease and Alzheimer's disease, ulcerative colitis, Crohn's disease, Diabetes mellitus, Rheumatoid Arthritis, AIDS, Renal diseases, Respiratory diseases and Eye diseases. To reduce the number of free radical-induced health problems, we need large amount of antioxidant nutrients along with less exposure to free radicals.

Oxygen is the major source of the potentially damaging free radicals, though it is essential for living. Free radicals are also there in the environment. Environmental sources which give rise to free radicals include exposure to ionizing radiation (from industry, sun exposure, cosmic rays, and medical X-rays), ozone and nitrous oxide (primarily from automobile exhaust), heavy metals (such as mercury, cadmium, and lead), cigarette smoke (both active and passive), alcohol, unsaturated fat, and other chemicals and compounds from food, water, and air $^{4}$.

Oxidation is a chemical reaction or process through which electrons are transferred between molecules by an oxidizing agent. Oxidation is a common and essential process in nature, but it can form free radicals inside human body which cause damage to healthy cells. This damage is known as oxidative stress ${ }^{5}$. Highly reactive oxygen species (ROS) and reactive nitrogen species (RNS) that possess an unpaired electron induce this stress. But cells are equipped to combat this oxidative attack with numerous cellular antioxidant defenses such as glutathione (GSH), superoxide dismutases, and catalase. During aging and various free radicals related disease states, these antioxidant defense systems can be changed leading to progressive oxidative damage and subsequent cell death and significant inactiveness. Changes in antioxidant level within specific cells and structures of the brain may be particularly useful in determining whether oxidative stress is benign or pathological ${ }^{6}$.

Molecules usually contain an even number, or paired electrons. Free radicals, however contain an uneven number of, or unpaired electrons. These electrons make free radicals unstable and highly reactive. Free radicals attack other molecules or healthy cell components in order to capture an electron, and thereby become stable. Subsequently, in the process, the original free radical creates a new free radical. A chain reaction of new free radicals is created due to this scavenging of electrons which eventually results in oxidative stress and damage to healthy cells. 
As the brain is the main target organ of oxidative stress; hence the researchers are studying about the correlation between enhanced levels of free radicals and neurodegenerative conditions.

Although free radicals are considered as harmful, they do perform some beneficial functions in the immune system. Free radicals help in the functioning of white blood cells as they attack bacterial invaders and other pathogens in the body. Free radicals are also thought to have a role in "redox signaling" process which assist to communicate between cells.

The main aim of antioxidants is to maintain the free radicals at optimum levels and not to completely destroy them as they do serve some useful functions also ${ }^{5}$.

\section{Different types of free radicals/oxidants and their defense system}

\author{
Free Radical \\ Hydroxy radical $\left(\mathrm{OH}^{*}\right)$ \\ Peroxy radical (ROO') \\ Oxidant \\ Superoxide anion $\left(\mathrm{O}_{2}{ }^{-}\right)$ \\ Hydrogen peroxide $\left(\mathrm{H}_{2} \mathrm{O}_{2}\right)$ \\ Hydroperoxides (HOD) \\ Transition metals $\left(\mathrm{Fe}^{2+}, \mathrm{Cu}^{+}\right)$
}

\section{Free Radical Scavenger}

(SOD), Mn-SOD, Cu-Zu-SOD

Tocopherols, Ubiquinone

$\frac{\text { Oxidant Scavenger }}{\text { Superoxide dismutases }}$
Catalase, glutathione peroxide (GPx)
GPx, glutathione reductase
Chelators

which can rapidly react with oxygen to form a lipid peroxyl radical (LOO·).

\section{Propagation:}

$$
\begin{gathered}
\mathrm{L} \cdot+\mathrm{O}_{2} \rightarrow \mathrm{LOO} \cdot \\
\mathrm{LOO} \cdot+\mathrm{LH} \rightarrow \mathrm{L} \cdot+\mathrm{LOOH}
\end{gathered}
$$

The peroxyl radicals are the chain carriers of the reaction; they can further oxidize the lipid, producing lipid hydroperoxides (LOOH), which in turn break down to a wide range of compounds, including alcohols, aldehydes, alkyl formates, ketones and hydrocarbons, and radicals, including the alkoxyl radical (LO·).

\section{Branching:}

$$
\begin{gathered}
\mathrm{LOOH} \rightarrow \mathrm{LO} \cdot+\mathrm{HO} \cdot \\
2 \mathrm{LOOH} \rightarrow \mathrm{LOO} \cdot+\mathrm{LO} \cdot+\mathrm{H}_{2} \mathrm{O}
\end{gathered}
$$

Primary antioxidants $(\mathrm{AH})$ when present in trace amounts, may either delay or inhibit the initiation step by reacting with a lipid radical or inhibit the propagation step by reacting with peroxyl or alkoxyl radicals. Secondary or preventative antioxidants are compounds that retard the rate of oxidation. This may be achieved in a number of ways, including removal of substrate or singlet oxygen quenching ${ }^{8}$.

$\mathrm{LOO}+\mathrm{AH} \rightarrow \mathrm{LOOH}+\mathrm{A}$

\section{CLASSIFICATION OF ANTIOXIDANTS ENZYMATIC ANTIOXIDANTS}

Antioxidant enzymes like SOD, GPx and CAT are the first lines of defense against $\mathrm{O}_{2}^{-}$and $\mathrm{H}_{2} \mathrm{O}_{2}^{-}$mediated injury.

Superoxide dismutase (SOD): Superoxide dismutase enzymes (family of metallo-enzymes) catalyze the dismutation of superoxide into oxygen and hydrogen
Where LH denotes the substrate molecule, such as, a lipid; R· as the initiating oxidizing radical. The oxidation of the lipid generates a highly reactive allyl radical $(\mathrm{L} \cdot)$ 
peroxide, they are an important antioxidant defense in nearly all cells exposed to oxygen. These enzymes are found in all aerobic organisms and also present in mitochondria and cytosol. There are four families of SODs: Cu-SOD, Cu-Zn-SOD, Mn-SOD and Fe-SOD enzyme and has been detected in a large number of tissues and organisms, and is thought that it is present to protect the cell from damage caused by $\mathrm{O}_{2}{ }^{\cdot-}$.

The SOD-catalysed dismutation of superoxide :

$$
\begin{gathered}
\mathrm{M}^{(\mathrm{n}+1)+}-\mathrm{SOD}+\mathrm{O}_{2}^{-} \rightarrow \mathrm{M}^{\mathrm{n}+}-\mathrm{SOD}+\mathrm{O}_{2} \\
\mathrm{M}^{\mathrm{n}+}-\mathrm{SOD}+\mathrm{O}_{2}^{-}+2 \mathrm{H}^{+} \rightarrow \mathrm{M}^{(\mathrm{n}+1)+}-\mathrm{SOD}+\mathrm{H}_{2} \mathrm{O}_{2}
\end{gathered}
$$$$
\text { where } \mathrm{M}=\mathrm{Cu}(\mathrm{n}=1) ; \mathrm{Mn}(\mathrm{n}=2) ; \mathrm{Fe}(\mathrm{n}=2) ; \mathrm{Ni}(\mathrm{n}=2) \text {. }
$$

In this reaction the oxidation state of the metal cation oscillates between $n$ and $n+1$.

Glutathione peroxidase (GPx) - Glutathione peroxidase (a selenium containing enzyme) involves in the reduction of $\mathrm{H}_{2} \mathrm{O}_{2}$ and lipid hydroperoxide $\left(\mathrm{LO}_{2} \mathrm{H}\right.$; generated during lipid peroxidation) to water using reduced glutathione as substrate. It is found in both cytosol and mitochondria and is a well-known first line of defense against oxidative stress, which in turn requires glutathione as a cofactor. Its involvement is noticed during generation of nucleotide precursors of DNA via the reduction of ribonucleotides to deoxyribonucleotides. GPx catalyses the oxidation of reduced glutathione (GSH) to oxidized glutathione (GSSG) at the expense of $\mathrm{H}_{2} \mathrm{O}_{2}$, by its selenium dependency. Since, selenium is an integral component of GPx, the measurement of this enzyme has been used as a functional index of selenium level. Low levels of selenium have been associated with a high risk of cardiovascular diseases and cancer in humans.

$$
2 \mathrm{GSH}+\mathrm{H}_{2} \mathrm{O}_{2} \rightarrow \mathrm{GS}-\mathrm{SG}+2 \mathrm{H}_{2} \mathrm{O} \text { (glutathione peroxidase) }
$$

Catalase (CAT) - Catalase (CAT) is present in most cells and catalyses the decomposition of hydrogen peroxide to water and oxygen. CAT is mainly localized in mitochondria and in subcellular respiratory organelles. The mechanism of action is as follows:

$$
2 \mathrm{H}_{2} \mathrm{O}_{2} \rightarrow 2 \mathrm{H}_{2} \mathrm{O}+\mathrm{O}_{2}
$$

In addition to the above enzymes, glutathione transferase, ceruloplasmin, hemoxygenase and possibly several other enzymes may participate in enzymatic control of oxygen radicals and their products ${ }^{9,10}$.

\section{NON ENZYMATIC ANTIOXIDANTS}

Antioxidative vitamins:- Antioxidative vitamins stimulates immune system, inhibit nitrosamine formation and alter metabolic activation of carcinogens. They inhibit DNA damage induced by ROMs and thus prevent genetic alterations. They protect the somatic cell from free radicals .

Vitamin A (Retinol, retinal) :- Vitamin A is a fatsoluble vitamin which includes the compounds -retinol and its esters, retinoldehyde and retinoic acid. It is essential for growth, maintenance of visual function, reproduction and differentiation of epithelial tissue. Betacarotene protects human body from sun light damage. $\beta$ carotene is part of a family of chemicals called the carotenoids, which are found in many fruit and vegetables, as well as some animal products such as egg yolks. Biologically, $\beta$-carotene is most important as the precursor of vitamin $\mathrm{A}$ in the human diet. It has antioxidant properties along with preventing cancer and other diseases. It is an excellent scavenger of singlet oxygen (produced during photosensitivity). Both natural and synthetic analogues of vitamin A have been shown to be effective in various diseases. Carrots, squash, sweet potatoes, peaches, kale and apricots are rich sources of $\square$-carotene. Vitamin A is structurally related to carotene. Carotene is converted into vitamin $\mathrm{A}$ in the liver. Two molecules of vitamin are formed from on molecule of beta carotene shown in the figure below ${ }^{9,11}$.<smiles>CC1=C(/C=C/C(C)=C/C=C/C(C)=C/C=C(C)/C=C(C)/C=C/C=C(C)/C=C/C2=C(C)CCCC2(C)C)C(C)(C)CCC1</smiles>

Beta Carotene

$\mathrm{O}_{2} \downarrow$ dioxygenase enzyme

2<smiles>CC1=C(/C=C/C(C)=C/C=C/C(C)=C/C=O)C(C)(C)CCC1</smiles>

Vitamin A

Figure 1: Conversion of Beta carotene to Vitamin $A^{11}$ 
Vitamin E (Tocopherol) :- This is a lipid soluble vitamin, which occurs in plasma as a variety of tocopherols, major one is alpha-tocopherol. It scavenges peroxy radical intermediates in lipid peroxidation and is responsible for protecting PUFA (Poly unsaturated fatty acid) present in cell membrane and low-density lipoprotein against lipid peroxidation. In addition to this, it's involvement in quenching of singlet oxygen and the reaction with peroxynitrite was noticed. Vitamin E works more efficiently in the lipid phase. Sources of vitamin E include wheat germ oil, nuts, seeds, whole grains, vegetable oil and fish liver oil. Chemical structure of Vitamin $\mathrm{E}$ is shown in the figure below ${ }^{9}$.

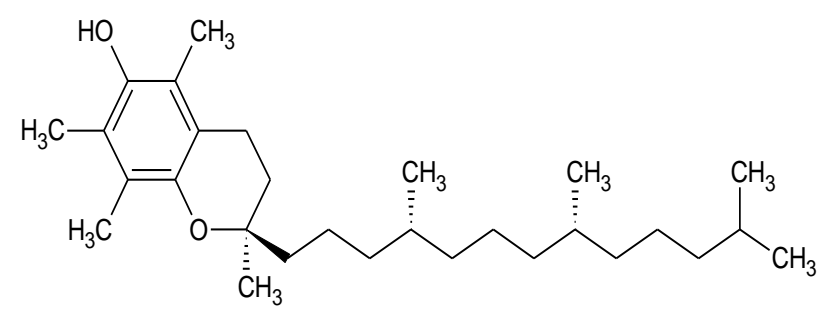

Figure 2: Vitamin $\mathrm{E}^{12}$

Vitamin C (Ascorbic acid) :- Vitamin C is a watersoluble antioxidant in biological fluids and its presence is also necessary for normal metabolic functions of the body. It interacts directly with radicals like $\mathrm{O}_{2}^{-}$and $\mathrm{HO}^{-}$ in plasma. It has been found that vitamin $\mathrm{C}$ is superior to over-the-counter medicines in reducing the symptoms, duration and severity of colds. It helps in cardiovascular disease by protecting the linings of arteries from oxidative damage. It neutralizes reactive oxygen metabolites and reduces oxidative DNA damage and genetic mutations. The rich source of this vitamin is citrus fruits, green vegetables, raw cabbage and tomatoes. Chemical structure of Vitamin $\mathrm{C}$ is shown here $^{9}$.<smiles>O=C1O[C@H]([C@@H](O)CO)C(O)=C1O</smiles>

Figure 3: Vitamin $\mathrm{C}^{12}$

Melatonin: Melatonin is a naturally occurring hormone found in animals and in some other living organisms, including algae. Unlike other antioxidants, melatonin does not undergo redox cycling. Melatonin, once oxidized, cannot be reduced to its former state because it forms several stable end-products upon reacting with free radicals. Therefore, it is referred to as a terminal antioxidant ${ }^{13}$.

Moreover numerous small molecules such as bilirubin, uric acid etc also act as antioxidants.

\section{ANTIOXIDANT PLANTS}

Plants are especially vulnerable to damage by active oxygen exposed to radiation, UV light. Hence, plants are equipped with numerous antioxidant defense systems that have resulted in certain numbers of very potent antioxidants. Beside plants, many of microbial and animal products as well as fermented products, seaweeds and protein hydrolysates were found to be powerful antioxidants. Antioxidant activity of plants may be attributed to presence of phenols, flavonoids, xanthones, alkaloids, anthraquinones, phytosterols, steroids, amino acids, isothiocyanate indoles etc.

Several antioxidants of plant origin are experimentally proved and used as effective protective agents against oxidative stress. Some of them are given below:

Black pepper - Piperine, a major constituent of Piper nigrum, enhances the synthesis of glutathione?

Resveratrol - It is a potent antioxidant with polyphenol compounds. It enhances nitric oxide activity and improve endothelial function. It is found in grapes and red wine ${ }^{7}$. Chemical structure of resveratrol is shown in Figure 4.<smiles>Oc1ccc(/C=C/c2cc(O)cc(O)c2)cc1</smiles>

Figure 4: Resveratrol ${ }^{14}$

Lutein - Lutein is a xanthophyll in the carotenoid family (shown in figure 5). It is plentiful in green leafy vegetables such as spinach, kale and yellow carrots. Lutein was found to be present in the macula, a small area of retina responsible for central vision. It was noticed that lutein helps keep the eyes safe from oxidative stress and the high-energy photons of blue light. Lutein can protect vision from cataracts and agerelated macular degeneration ${ }^{15}$.<smiles>CC1=C(/C=C/C=C/C(C)=C/C=C/C(C)=C/C=C/C=C(C)/C=C/C2=C(C)CC(O)CC2(C)C)C(C)(C)CC(O)C1</smiles>

Figure 5: Lutein ${ }^{16}$

Pine Bark Extract: Pine bark extract is a rich source of procyanidin oligomers, which increase antioxidant activity. It improves glutathione levels. The active components of pine bark extract act as anti-inflammatory agent.

Quercetin - Quercetin is a phytochemical with high antioxidant activity that has been shown to maintain blood pressure levels and thus benefit cardiovascular function. Quercetin can inhibit platelet aggregation, increase nitric oxide activity and improve endothelial function. It is found in apples and onions ${ }^{7}$.

Nowadays, several synthetic antioxidant supplements based on glutathione are available in the market which are summerised below ${ }^{[17,18]}$. 


\section{Brand Name}

Glutathione Complex

Glutathione Booster

Mega L- Glutathione

Reduced Glutathione 50mg

Gluton Inj $600 \mathrm{mg}$
Formulation

Tablets

Capsules

Tablets

Capsules

Injection

A brief description including part used, chemical constituents and other biological activities of the common antioxidant plants is given in Table 1 and an additional list of antioxidant plants is shown in Table 2.

\section{TABLE 1: LIST OF ANTIOXIDANT PLANT SOURCES ${ }^{19-21}$}

\begin{tabular}{|c|c|c|c|c|}
\hline S.N. & Common Name & Chemical Constituents & $\begin{array}{l}\text { Part } \\
\text { Used }\end{array}$ & Biological Activities \\
\hline 1 & Akashabela & $\begin{array}{l}\text { Flavonoids, glycosides, lactones, } \\
\text { coumarins, dulcitol, bergenin }\end{array}$ & Stem & $\begin{array}{l}\text { Expectorant, anthelmintic, purgative, } \\
\text { diuretic, in jaundice, antifertility drug. }\end{array}$ \\
\hline \multirow[t]{3}{*}{2} & \multirow[t]{3}{*}{ Am/Mango } & \multirow{3}{*}{$\begin{array}{l}\text { Cyanogenetic glycosides, } \\
\text { mangiferin, quercetin, ellagic } \\
\text { acid, gallic acid }\end{array}$} & Fruit & $\begin{array}{l}\text { Prevention of cancer (colon, breast, } \\
\text { leukemia) }\end{array}$ \\
\hline & & & Leaf & Antibacterial \\
\hline & & & Root & Leucorrhoea, diarrhoea \\
\hline 3 & Amla/Myrobalan & $\begin{array}{l}\text { Vitamin C (L-ascorbic acid, } \\
\text { polyphenols (ellagic acid, gallic } \\
\text { acid, tannins) }\end{array}$ & Fruit & $\begin{array}{l}\text { Useful in burning sensations, piles, } \\
\text { leprosy, inflammations, anaemia, urinary } \\
\text { discharges, constipation }\end{array}$ \\
\hline \multirow[t]{3}{*}{4} & \multirow[t]{3}{*}{ Ashwagandha } & \multirow{3}{*}{$\begin{array}{l}\text { Steroidal lactones, glycene, } \\
\text { withanine, withanolides }\end{array}$} & Leaf & Immunomodulator \\
\hline & & & Root & Analgesic \\
\hline & & & Seed & Diuretic and hypnotic \\
\hline 5 & Babchi & $\begin{array}{l}\text { Essential oil, fixed oil, resin, } \\
\text { bakuchiol }\end{array}$ & Seed & $\begin{array}{l}\text { Purgative, stomachic, stimulant, } \\
\text { anthelmintic, aphrodisiac, in scabies }\end{array}$ \\
\hline 6 & Carrot & $\begin{array}{l}\text { Carotene, carotenoids, sugars, } \\
\text { glycosides, } \\
\text { quarternary bases }\end{array}$ & Root & $\begin{array}{l}\text { Used in bronchitis, piles, jaundice, } \\
\text { tumours, leprosy, urinary complaints, } \\
\text { chest troubles, aphrodisiac }\end{array}$ \\
\hline 7 & Chirayita/Chiretta & $\begin{array}{l}\text { Xanthones, mangiferin, } \\
\text { swertinin, chiratin, arginine }\end{array}$ & $\begin{array}{l}\text { Whole } \\
\text { plant }\end{array}$ & $\begin{array}{l}\text { Febrifuge, laxative, } \\
\text { antimalarial, chronic fever }\end{array}$ \\
\hline \multirow[t]{4}{*}{8} & \multirow[t]{4}{*}{$\begin{array}{l}\text { Karela/Bitter } \\
\text { Melon }\end{array}$} & \multirow[t]{4}{*}{ Stearic acid, triterpene glycosides } & Fruit & $\begin{array}{l}\text { Fruit as stomachic, aphrodisiac, } \\
\text { increases immunity }\end{array}$ \\
\hline & & & Leaf & Antidiabetic \\
\hline & & & Root & Laxative, antipyretic \\
\hline & & & Seed & Stomachic, aphrodisiac \\
\hline 9 & $\begin{array}{l}\text { Makoi/Common } \\
\text { nightshade }\end{array}$ & $\begin{array}{l}\text { Polyphenolic } \\
\text { flavonoids, steroids }\end{array}$ & Leaf & $\begin{array}{l}\text { Polyphenolic compounds, flavonoids, } \\
\text { steroids }\end{array}$ \\
\hline 10 & Mulethi/Liquorice & $\begin{array}{l}\text { Glycyrrhizin, flavonoids, } \\
\text { liquiritin, isoliquiritin }\end{array}$ & Root & $\begin{array}{l}\text { Diuretic, emmenagogue, in vomiting, } \\
\text { asthma, peptic ulcer, bronchitis, for } \\
\text { curing wounds }\end{array}$ \\
\hline 11 & $\begin{array}{l}\text { Safed } \\
\text { Chandan/Sandal }\end{array}$ & $\begin{array}{l}\text { Volatile oil, santalol, } \alpha \text {-santalol, } \\
\beta \text {-santalol, } \beta \text {-sitosterol }\end{array}$ & $\begin{array}{l}\text { Heart } \\
\text { wood }\end{array}$ & $\begin{array}{l}\text { Antipyretic, aphrodisiac, in heart } \\
\text { diseases, bronchitis, small pox, used in } \\
\text { perfumery }\end{array}$ \\
\hline 12 & Saunf/Fennel & $\begin{array}{l}\text { Volatile oil, fenchone, anethole, } \\
\text { limonene, estragole }\end{array}$ & $\begin{array}{l}\text { Fruit } \\
\text { oil }\end{array}$ & $\begin{array}{l}\text { Stimulant, purgative, diuretic, useful in } \\
\text { venereal diseases, vermicide }\end{array}$ \\
\hline 13 & Tulsi/Sacred Basil & $\begin{array}{l}\text { Volatile oil, terpenoids, eugenol, } \\
\text { thymol, estragole }\end{array}$ & Leaf & $\begin{array}{l}\text { Expectorant, in catarrh, bronchitis, } \\
\text { ringworm, stomachic, in earache }\end{array}$ \\
\hline
\end{tabular}


Table 2: ADDITIONAL LIST OF PLANTS WITH ANTIOXIDANT ACTIVITY ${ }^{22-34}$

\begin{tabular}{|c|c|c|}
\hline Part used & Botanical Name & Family \\
\hline Aerial parts & $\begin{array}{l}\text { Baccharis coridifolia } \text { DC. } \\
\text { Lavandula angustifolia Mill. } \\
\text { Melissa officinalis } \text { Linn. } \\
\text { Rosmarinus officinalis Linn. } \\
\text { Salvia officinalis Linn. } \\
\text { Thymus zygis } \text { Sibth. \& Sm. }\end{array}$ & $\begin{array}{l}\text { Asteraceae } \\
\text { Lamiaceae } \\
\text { Lamiaceae } \\
\text { Lamiaceae } \\
\text { Lamiaceae } \\
\text { Lamiaceae }\end{array}$ \\
\hline Bark & $\begin{array}{l}\text { Cinnamomum zeylanicum Breyn. } \\
\text { Uncaria tomentosa DC. } \\
\text { Lannea acida }\end{array}$ & $\begin{array}{c}\text { Lauraceae } \\
\text { Rubiaceae } \\
\text { Anacardiaceae }\end{array}$ \\
\hline Bulb & Allium sativum Linn. & Liliaceae \\
\hline Essential oil & $\begin{array}{l}\text { Crithmum maritimum Linn. } \\
\text { Ocimum basillicum } \\
\text { Anethum graveolens } \\
\text { Cymbopogon winterianus } \\
\text { Syzygium aromaticum } \\
\text { Thymus vulgaris }\end{array}$ & $\begin{array}{c}\text { Apiaceae } \\
\text { Lamiaceae } \\
\text { Apiaceae } \\
\text { Poaceae } \\
\text { Myrtaceae } \\
\text { Lamiaceae }\end{array}$ \\
\hline Flower buds & $\begin{array}{l}\text { Syzygium caryophyllatum (Linn.)Alston syn.Eugenia caryophyllus Wight } \\
\text { Matricaria chamomilla }\end{array}$ & $\begin{array}{l}\text { Myrtaceae } \\
\text { Asteraceae }\end{array}$ \\
\hline Fruits & $\begin{array}{l}\text { Garcinia kola Heckel } \\
\text { Lycium barbarum Linn. } \\
\text { Myrica gale Linn. } \\
\text { Piper nigrum } \text { Linn. } \\
\text { Prunus domestica } \text { Linn. } \\
\text { Solanum melongena } \text { Linn. } \\
\text { Vitis rotundifolia } \\
\text { Kigelia Africana } \\
\text { Crataegus pubescens (C. Presl) } \\
\text { Ligustrum lucidum }\end{array}$ & $\begin{array}{c}\text { Clusiaceae } \\
\text { Solanaceae } \\
\text { Myricaceae } \\
\text { Piperaceae } \\
\text { Rosaceae } \\
\text { Solanaceae } \\
\text { Vitaceae } \\
\text { Bignoniaceae } \\
\text { Rosaceae } \\
\text { Oleaceae }\end{array}$ \\
\hline Grain & Triticum durum Desf & Poaceae \\
\hline Leaf & $\begin{array}{l}\text { Cichorium intybus } \text { Linn. } \\
\text { Cynara scolymus } \text { Linn. } \\
\text { Emilia sonchifolia } \text { DC. } \\
\text { Eucalyptus camaldulensis Dehnh. syn. Eucalyptus rostrata } \text { Schl. } \\
\text { Eucommia ulmoids } \text { Oliver } \\
\text { Ginkgo biloba } \text { Linn. } \\
\text { Murraya koenigii (Linn.) Spreng. } \\
\text { Rhazya stricta } \text { Decne } \\
\text { Salvia triloba } \text { Linn. f. } \\
\text { Enicostemma axillare (Lam.) Raynal. } \\
\text { Aloysia triphylla }\end{array}$ & $\begin{array}{c}\text { Asteraceae } \\
\text { Asteraceae } \\
\text { Asteraceae } \\
\text { Myrtaceae } \\
\text { Eucommiaceae } \\
\text { Ginkgoaceae } \\
\text { Rutaceae } \\
\text { Apocyanaceae } \\
\text { Lamiaceae } \\
\text { Gentianaceae } \\
\text { Verbenaceae }\end{array}$ \\
\hline
\end{tabular}




\begin{tabular}{|c|c|c|}
\hline & $\begin{array}{l}\text { Ferula foetida } \\
\text { Camellia sinensis } \\
\text { Bacopa monnieri } \\
\text { Salvia hypoleuca }\end{array}$ & $\begin{array}{c}\text { Apiaceae } \\
\text { Theaceae } \\
\text { Scrophulariaceae } \\
\text { Lamiaceae }\end{array}$ \\
\hline Leaves \& Fruit & Ipomoea batatas (L.) Lam. & Convolvulaceae \\
\hline Leaves \& Root & Punica granatum & Lythraceae \\
\hline Peels \& Seeds & Citrus sinensis & Rutaceae \\
\hline Rhizome & $\begin{array}{l}\text { Zingiber officinale Rosc. } \\
\text { Curculigo orchioides Gaertn. }\end{array}$ & $\begin{array}{l}\text { Zingiberaceae } \\
\text { Hypoxidaceae }\end{array}$ \\
\hline Rhizome \& Root & Picrorrhiza kurroa & Scrophulariaceae \\
\hline Root & $\begin{array}{l}\text { Bryonia alba } \text { Linn. } \\
\text { Panax ginseng Mey. } \\
\text { Tinospora cordifolia (Willd.) Miers. ex Hook. f.\& Thoms. } \\
\text { Medicago sativa } \mathbf{L} . \\
\text { Rhodiola rosea } \\
\text { Ferula hermonis } \\
\text { Polygonum multiflorum }\end{array}$ & $\begin{array}{l}\text { Cucurbitaceae } \\
\text { Araliaceae } \\
\text { Menispermaceae } \\
\text { Fabaceae } \\
\text { Crassulaceae } \\
\text { Apiaceae } \\
\text { Polygonaceae }\end{array}$ \\
\hline Seed & $\begin{array}{l}\text { Plantago asiatica Linn. } \\
\text { Cassia auriculata } \\
\text { Artemisia annua } \mathbf{L} \text {. } \\
\text { Daucus carota } \\
\text { Momordica charantia }\end{array}$ & $\begin{array}{c}\text { Plantaginaceae } \\
\text { Caesalpiniaceae } \\
\text { Asteraceae } \\
\text { Apiaceae } \\
\text { Cucurbitaceae }\end{array}$ \\
\hline Shoot & Asparagus racemosus Willd. & Liliaceae \\
\hline Tuber & Solanum tuberosum Linn. & Solanaceae \\
\hline Whole plant & $\begin{array}{l}\text { Sida cordifolia } \\
\text { Dana racemosa } \\
\text { Yucca schidigera }\end{array}$ & $\begin{array}{c}\text { Malvaceae } \\
\text { Asparagaceae } \\
\text { Asparagaceae }\end{array}$ \\
\hline
\end{tabular}

Some of the common antioxidant food sources are shown below:

Table 3: Common Antioxidant Food Sources ${ }^{35-39}$

\begin{tabular}{|c|c|c|c|}
\hline SL. NO. & Name of the Food Item & SL. NO. & Name of the Food Item \\
\hline $\mathbf{1}$ & Almond & $\mathbf{2 6}$ & Kidney beans \\
\hline $\mathbf{2}$ & Apricot & $\mathbf{2 7}$ & Mango \\
\hline $\mathbf{3}$ & Artichoke & $\mathbf{2 8}$ & Molasses \\
\hline $\mathbf{4}$ & Barley & $\mathbf{2 9}$ & Olive oil \\
\hline $\mathbf{5}$ & Blackberry & $\mathbf{3 0}$ & Onion \\
\hline $\mathbf{6}$ & Black bean & $\mathbf{3 1}$ & Papaya \\
\hline $\mathbf{7}$ & Black plum & $\mathbf{3 2}$ & Pecan \\
\hline $\mathbf{8}$ & Brazil nuts & $\mathbf{3 3}$ & Pineapple \\
\hline $\mathbf{9}$ & Broccoli & $\mathbf{3 4}$ & Plum beans \\
\hline $\mathbf{1 0}$ & Brussel sprouts & $\mathbf{3 5}$ & Prune \\
\hline $\mathbf{1 1}$ & Cantaloupe & $\mathbf{3 6}$ & Raisins \\
\hline $\mathbf{1 2}$ & Carrot & $\mathbf{3 7}$ & Raspberry \\
\hline $\mathbf{1 3}$ & Cinnamon & $\mathbf{3 8}$ & Red delicious apple \\
\hline $\mathbf{1 4}$ & Clove & $\mathbf{3 9}$ & \\
\hline
\end{tabular}




\begin{tabular}{|l|c|c|c|}
\hline $\mathbf{1 5}$ & Cocoa powder & $\mathbf{4 0}$ & Russet potato \\
\hline $\mathbf{1 6}$ & Coffee & $\mathbf{4 1}$ & Salmon \\
\hline $\mathbf{1 7}$ & Cottonseed oil & $\mathbf{4 2}$ & Small red beans \\
\hline $\mathbf{1 8}$ & Cranberry & $\mathbf{4 3}$ & Sorghum \\
\hline $\mathbf{1 9}$ & Cultivated Blueberry & $\mathbf{4 4}$ & Strawberry \\
\hline $\mathbf{2 0}$ & Eggs & $\mathbf{4 5}$ & Tomato \\
\hline $\mathbf{2 1}$ & Gala apple & $\mathbf{4 6}$ & Vanilla beans \\
\hline $\mathbf{2 2}$ & Ginger roots & $\mathbf{4 7}$ & Walnut \\
\hline $\mathbf{2 3}$ & Granny smith apple & $\mathbf{4 8}$ & Watercress \\
\hline $\mathbf{2 4}$ & Green peppers & $\mathbf{4 9}$ & Wild blueberry \\
\hline $\mathbf{2 5}$ & Guava & $\mathbf{5 0}$ & \\
\hline
\end{tabular}

\section{ANTIOXIDANT ACTIVITY OF ESSENTIAL OILS}

A study was done on 248 essential oils belonging to 18 botanical families for the presence of antioxidant potential. The antioxidant activities of the oils were tested by DPPH radical scavenging activity at three different concentrations of 5, 25 and $100 \mathrm{mg} / \mathrm{mL}$ using $\%$ DPPH inhibition and then further evaluated by TLC. Thin layer chromatography regions responsible for the antioxidant activity were examined by GC/MS and the active components responsible for the activity were identified based on their mass spectra and GC retention times. Among them, 60 essential oils were found to be active at a concentration of $100 \mathrm{mg} / \mathrm{mL}, 27$ of them at 25 $\mathrm{mg} / \mathrm{mL} \& 17$ of them were active at $5 \mathrm{mg} / \mathrm{mL}$ concentration. Essential oils belonging to the family Annonaceae, Apiaceae, Asteraceae, Burseraceae, Cupressaceae, Fabaceae, Geraniaceae, Lamiaceae, Lauraceae, Myrtaceae, Myristicaceae, Myoporceae, Piperaceae, Poaceae, Rosaceae, Rutaceae, Rubiaceae, Solanaceae and Moschidae were the most effective essential oils. Out of the 18 constituents identified, 7 of them were aromatic hydrocarbons or phenolic compounds and 14 of the identified compounds were oxygenated monoterpenoids ${ }^{40}$.<smiles>CC12CCC(C)(C(=O)C1)C2(C)C</smiles>

Camphor<smiles>Cc1ccc(C(C)CCl)cc1</smiles><smiles>Cc1ccc(C(C)C)c(O)c1</smiles><smiles>CC(=O)OC(C)c1ccc(C)c(O)c1</smiles><smiles>O=Cc1ccc(O)c(O)c1</smiles>

Vanillin<smiles>C=CCc1ccc(O)c(OC)c1</smiles>

Eugenol

Figure 6: Chemical Structure of Active Antioxidant Compounds ${ }^{40}$

Another study was reported on the Oregano (Origanum vulgare L., ssp. hirtum) essential oils to reveal the antioxidative properties in which three different methods were employed to assess the activity namely $\beta$-carotene bleaching test, DPPH radical scavenging method and Thiobarbituric acid reactive species assay. 17 compounds were identified in hydrocarbons fraction with $\gamma$-terpinene (31.0\%), $p$-cymene $(22.1 \%), \alpha$-terpinene $(10.4 \%)$ and transcaryophyllene $(9.1 \%)$ as main components. There were 4 oxygen-containing compounds, out of which, thymol $(47.3 \%)$ and carvacrol $(46.4 \%)$ were the major ones. The phenolic fraction contained only 2 compounds, thymol $(58.9 \%)$ and carvacrol $(41.1 \%)$. It was seen that the BCB method can be helpful especially for the investigation of the antioxidant activity of essential oils. On the other hand, the DPPH method is faster than BCB method and it is useful in giving preliminary information of radical scavenging abilities of novel antioxidants. The method is sensitive and requires small sample amounts. The TBA method is preferable in order to obtain useful data in an environment similar to the real-life situation. Both methods, DPPH and TBA, similarly allow testing of both lipophilic and hydrophilic substances. In the study, it was confirmed that the same antioxidant samples exhibit different antioxidative values depending on the concentration and the measured antioxidant parameter. This study confirmed that the oregano essential oil possess remarkable antioxidant properties. The antioxidant effect was due to the presence of thymol and carvacrol, but a possible synergistic effect among oxygen containing compounds could be suggested too ${ }^{41}$.

\section{ANTIOXIDANT ASSAY METHODS}

Antioxidant activity should not be concluded based on a single antioxidant test model. Generally various antioxidant assay methods are employed to assess the samples of interest. Researcher

has to critically verify methods of analysis before adopting the choice of method. Various in vitro and in vivo methods are described here:-

\section{In-vitro methods}

DPPH Radical Scavenging Activity - The molecule 1,1-diphenyl-2-picrylhydrazyl ( $\alpha, \alpha$-diphenylbpicrylhydrazyl; DPPH) is a stable free radical by virtue of the delocalisation of the spare electron over the 
molecule as a whole, so that the molecule does not dimerize. The delocalization of electron also gives rise to the deep violet color, characterized by an absorption band centered at about $517 \mathrm{~nm}$. When a solution of DPPH is mixed with that of a substrate $(\mathrm{AH})$ that can donate a hydrogen atom, then this gives rise to the reduced form and the colour changes from violet to colourless or pale yellow. Alam MN et al reported that the sample extract $(0.2 \mathrm{~mL})$ was mixed with methanol and $2 \mathrm{~mL}$ of DPPH solution $(0.5 \mathrm{mM})$. After $30 \mathrm{~min}$, the absorbance was measured at $517 \mathrm{~nm}$. The percentage of the DPPH radical scavenging was calculated using the equation as given below:

$$
\% \text { inhibition of DPPH radical }=\left(\left[\mathrm{A}_{\mathrm{br}}-\mathrm{A}_{\mathrm{ar}}\right] / \mathrm{A}_{\mathrm{br}}\right) \times 100
$$

where $A_{b r}$ was the absorbance before reaction and $A_{a r}$ was the absorbance after reaction has taken place.

Hydrogen Peroxide Scavenging $\left(\mathrm{H}_{2} \mathrm{O}_{2}\right)$ Assay $-\mathrm{H}_{2} \mathrm{O}_{2}$ is rapidly decomposed into oxygen and water and this may produce hydroxyl radicals $(\mathrm{OH})$ that can initiate lipid peroxidation and cause DNA damage in the body. According to Alam MN et al, the ability of plant extracts to scavenge $\mathrm{H}_{2} \mathrm{O}_{2}$ can be estimated. In this method, phosphate buffer was used as blank solution and the absorbance was checked at $230 \mathrm{~nm}$. The percentage of hydrogen peroxide scavenging was calculated as follows:

$$
\% \text { scavenged } \mathrm{H}_{2} \mathrm{O}_{2}=\left[\left(A_{i}-A_{t}\right) / A_{i}\right] \times 100
$$

where $A_{i}$ was the absorbance of control and $A_{t}$ was the absorbance of test.

Nitric oxide scavenging activity $-\mathrm{NO}^{-}$is generated in biological tissues by specific nitric oxide

synthases, which metabolizes arginine to citrulline with the formation of $\mathrm{NO}^{-}$via a five electron oxidative reaction. Alam $\mathrm{MN}$ et al reported that, $2 \mathrm{~mL}$ of $10 \mathrm{mM}$ sodium nitroprusside dissolved in $0.5 \mathrm{~mL}$ phosphate buffer saline ( $\mathrm{pH} \mathrm{7.4)}$ is mixed with $0.5 \mathrm{~mL}$ of sample at various concentrations $(0.2-0.8 \mathrm{mg} / \mathrm{mL})$. After $150 \mathrm{~min}$ of incubation at $25^{\circ} \mathrm{C}, 0.5 \mathrm{~mL}$ of the incubated solution is withdrawn and mixed with $0.5 \mathrm{~mL}$ of Griess reagent [ $(1.0 \mathrm{~mL}$ sulfanilic acid reagent $(0.33 \%$ in $20 \%$ glacial acetic acid at room temperature for 5 min with $1 \mathrm{~mL}$ of naphthylethylenediamine dichloride $(0.1 \%$ w/v $)]$. After incubation for $30 \mathrm{~min}$ and its absorbance was measured at $546 \mathrm{~nm}$. The amount of nitric oxide radical inhibition was calculated following this equation:

$$
\% \text { inhibition of } N O \text { radical }=\left[A_{0}-A_{I}\right] / A_{0} \times 100
$$

where $\mathrm{A}_{0}$ was the absorbance before reaction and $\mathrm{A}_{1}$ was the absorbance after reaction with Griess reagent.

Trolox Equivalent Antioxidant Capacity (TEAC) method/ ABTS Radical Cation Decolorization Assay This method, uses a diode-array spectrophotometer to measure the loss of color when an antioxidant is added to the blue-green chromophore ABTS. +(2,2-azino-bis(3ethylbenzthiazoline-6-sulfonic acid)). The antioxidant reduces ABTS.+ to ABTS and decolorize it. ABTS.+ is a stable radical not found in the human body. Trolox (6hydroxy-2,5,7,8-tetramethylchroman-2 carboxylic acid), a water-soluble analog of vitamin $\mathrm{E}$, was used as an antioxidant standard and absorbance is read (at $750 \mathrm{~nm}$ ) after $5 \mathrm{~min}$. TEAC values can be calculated from the
Trolox standard curve and expressed as Trolox equivalents (in $\mathrm{mM}$ ).

Total radical-trapping antioxidant parameter (TRAP) method - This method is based on the protection provided by antioxidants on the fluorescence decay of R-phycoerythrin (R-PE) during a controlled peroxidation reaction. The antioxidative potential is evaluated by measuring the decay in decoloration. 120 $\mu \mathrm{L}$ of diluted sample is added to $2.4 \mathrm{~mL}$ of phosphate buffer ( $\mathrm{pH} 7.4), 375 \mu \mathrm{L}$ of bidistilled water, $30 \mu \mathrm{L}$ of diluted R-PE and $75 \mu \mathrm{L}$ of ABAP; the reaction kinetics at $38{ }^{\circ} \mathrm{C}$ is recorded for $45 \mathrm{~min}$ by a luminescence spectrometer. TRAP values are calculated from the length of the lag-phase due to the sample compared with standard.

Ferric reducing-antioxidant power (FRAP) assay - It is based on the reduction of the complex of ferric iron and 2,3,5-triphenyl-1,3,4-triaza-2-azoniacyclopenta-1,4diene chloride (TPTZ) to the ferrous form at low $\mathrm{pH}$. According to Alam MN et al, $3 \mathrm{~mL}$ of prepared FRAP reagent is mixed with $100 \mu \mathrm{L}$ of diluted sample; the absorbance at $593 \mathrm{~nm}$ is recorded after a $30 \mathrm{~min}$ incubation at $37{ }^{\circ} \mathrm{C}$. FRAP values can be obtained by comparing the absorption change in the test mixture with those obtained from increasing concentrations of $\mathrm{Fe}^{3+}$ and expressed as $\mathrm{mM}$ of $\mathrm{Fe}^{2+}$ equivalents per $\mathrm{kg}$ (solid food) or per L (beverages) of sample.

Superoxide radical scavenging activity (SOD) Although superoxide anion is a weak oxidant, it ultimately produces powerful and dangerous hydroxyl radicals as well as singlet oxygen, both of which contribute to oxidative stress. The superoxide anion radicals are generated in $3.0 \mathrm{~mL}$ of Tris- $\mathrm{HCl}$ buffer $(16$ $\mathrm{mM}, \mathrm{pH} 8.0)$, containing $0.5 \mathrm{~mL}$ of nitroblue tetrazolium (NBT) $(0.3 \mathrm{mM}), 0.5 \mathrm{~mL}$ NADH $(0.936 \mathrm{mM})$ solution, $1.0 \mathrm{~mL}$ extract and $0.5 \mathrm{~mL}$, Tris- $\mathrm{HCl}$ buffer $(16 \mathrm{mM}, \mathrm{pH}$ 8.0). The reaction is initiated by adding $0.5 \mathrm{~mL}$ phenazine methosulfate (PMS) solution $(0.12 \mathrm{mM})$ to the mixture, incubated at $25{ }^{\circ} \mathrm{C}$ for $5 \mathrm{~min}$ and then the absorbance is measured at $560 \mathrm{~nm}$ against a blank sample.

Thiobarbituric acid (TBA) method - The final sample concentration of $0.02 \% \mathrm{w} / \mathrm{v}$ was used in this method. 2 $\mathrm{mL}$ of $20 \%$ trichloroacetic acid and $2 \mathrm{~mL}$ of $0.67 \%$ of thiobarbituric acid were added to $1 \mathrm{~mL}$ of sample solution. The mixture was placed in a boiling water bath for $10 \mathrm{~min}$ and then centrifuged after cooling at 3000 $\mathrm{rpm}$ for $20 \mathrm{~min}$. The absorbance activity of the supernatant was measured at $552 \mathrm{~nm}$ and recorded after it has reached its maximum.

Hydroxyl radical scavenging activity - Hydroxyl radical is one of the potent reactive oxygen species in the biological system that reacts with polyunsaturated fatty acid moieties of cell membrane phospholipids and causes damage to cell. The reaction mixture $(1.0 \mathrm{~mL})$ consist of $100 \mu \mathrm{L}$ of 2-deoxy- Dribose (28 $\mathrm{mM}$ in $20 \mathrm{mM}$ KH2PO4-KOH buffer, $\mathrm{pH} 7.4), 500 \mu \mathrm{L}$ of the extract, $200 \mu \mathrm{L}$ EDTA $(1.04 \mathrm{mM})$ and $200 \mu \mathrm{M} \mathrm{FeCl} 3(1: 1 \mathrm{v} / \mathrm{v})$, $100 \mu \mathrm{L}$ of $\mathrm{H}_{2} \mathrm{O}_{2}(1.0 \mathrm{mM})$ and $100 \mu \mathrm{L}$ ascorbic acid (1.0 $\mathrm{mM}$ ) which is incubated at $37{ }^{\circ} \mathrm{C}$ for $1 \mathrm{~h}$. One milliliter of thiobarbituric acid $(1 \%)$ and $1.0 \mathrm{~mL}$ of trichloroacetic acid $(2.8 \%)$ are added and incubated at $100{ }^{\circ} \mathrm{C}$ for 20 ISSN: 2250-1177

CODEN (USA): JDDTAO 
min. After cooling, absorbance is measured at $532 \mathrm{~nm}$, against a blank sample ${ }^{42}$.

Hypochlorite scavenging assay - The reaction mixture contained taurine $(150 \mathrm{mM})$, sodium

hypochlorite $(600 \mathrm{mM})$, reference compounds (variable concentrations) and phosphate saline buffer ( $\mathrm{pH} 7.4)$ in a final volume of $1 \mathrm{~mL}$. The solution was mixed thoroughly and potassium iodide ( $2 \mathrm{M}$ ) was added. A yellow coloration was developed and the absorbance was read at $350 \mathrm{~nm}^{43}$.

Other methods include Oxygen radical absorbance capacity (ORAC) method, Hydroxyl radical averting capacity (HORAC) method, Peroxynitrite radical scavenging activity, Reducing power method (RP), Phosphomolybdenum method, Ferric thiocyanate (FTC) method, DMPD (N,N-dimethyl-p-phenylene diamine dihydrochloride) method, $\beta$-carotene linoleic acid method /conjugated diene assay, Copper-phenanthroline (Cu-phen) assay, Deoxyribose assay, Xanthine oxidase method, Cupric ion reducing antioxidant capacity (CUPRAC) method, Metal chelating activity, LOX/RNO method, Galvinoxyl radical-scavenging assay ${ }^{44}$, Oxidative hemolysis inhibition assay (OxHLIA) ${ }^{[44]}$, Total oxyradical scavenging activity(TOSC ${ }^{45}$.

\section{In-vivo methods}

Glutathione-S-transferase (GSt) - These enzymes catalyze the reaction of such compounds with the -SH group of glutathione, thereby neutralizing their electrophilic sites and rendering the products more water-soluble. The reaction mixture $(1 \mathrm{~mL})$ consisted of $0.1 \mathrm{~N}$ potassium phosphate ( $\mathrm{pH} 6.5), 1 \mathrm{nM} / \mathrm{L} \mathrm{GSt}, 1 \mathrm{M} / \mathrm{L}$ 1-chloro-2, 4-dinitrobenzene as substrate and a suitable amount of cytosol $(6 \mathrm{mg}$ protein $/ \mathrm{mL})$. The reaction mixture is incubated at $37{ }^{\circ} \mathrm{C}$ for $5 \mathrm{~min}$ and the reaction is initiated by the addition of the substrate. The increase in absorbance at $340 \mathrm{~nm}$ was measured spectrophotometrically.

Catalase (CAT) - Catalase activity can be determined in erythrocyte lysate. $50 \mu \mathrm{L}$ of the lysate is added to a cuvette containing $2 \mathrm{~mL}$ of phosphate buffer $(\mathrm{pH} 7.0)$ and $1 \mathrm{~mL}$ of $30 \mathrm{mM} \mathrm{H} \mathrm{O}_{2}$. Catalase activity is measured at $240 \mathrm{~nm}$ for $1 \mathrm{~min}$ using spectrophotometer. The molar extinction coefficient of $\mathrm{H}_{2} \mathrm{O}_{2}, 43.6 \mathrm{M} \mathrm{cm}^{-1}$ was used to determine the catalase activity.

$\boldsymbol{\gamma}$-Glutamyl transpeptidase activity (GGT) assay - The serum sample is added to a substrate solution containing glycylglycine, $\mathrm{MgCl}_{2}$ and g-Glutamyl-p-nitroanilide in $0.05 \mathrm{M}$ tris (free base), $\mathrm{pH}$ 8.2. The mixture is incubated at $37{ }^{\circ} \mathrm{C}$ for $1 \mathrm{~min}$ and the absorbance read at $405 \mathrm{~nm}$ at $1 \mathrm{~m}$ interval for $5 \mathrm{~m}$.

Superoxide dismutase (SOD) method - It is estimated in the erythrocyte lysate prepared from the 5\% RBC suspension. To $50 \mu \mathrm{L}$ of the lysate, $75 \mathrm{mM}$ of Tris- $\mathrm{HCl}$ buffer (pH 8.2), $30 \mathrm{mM}$ EDTA and $2 \mathrm{mM}$ of pyrogallol are added. An increase in absorbance is recorded at 420 $\mathrm{nm}$ for $3 \mathrm{~min}$ by spectrophotometer ${ }^{42}$.

Others include Ferric reducing ability of plasma, LDL assay, Reduced glutathione (GSH) estimation, Glutathione peroxidase (GSHPx) estimation, Glutathione reductase (GR) assay, Lipid peroxidation (LPO) assay, Cellular antioxidant activity (CAA) assay ${ }^{46}$.

\section{CONCLUSION}

From the above discussion, it has been found that free radical contributes to the etiology of various ailments. Antioxidants can prevent the risk of so many diseases by interacting with free radicals. A number of active constituents including vitamins are found exogenously in nature which serve as useful antioxidants. Various synthetic antioxidant supplements are also found in the market now-a-days. Both of them provide health benefits against oxidative stress. Thus this study elaborates the potential of antioxidants to protect us from numerous health disorders. In near future, different combinations of the active antioxidant constituents should be made and checked for the synergistic effect. Moreover, a fusion of the modern analytical technologies with ethnic medicinal system should be done for unveiling the antioxidative potential of different sources. 


\section{REFERENCES}

1. http://www.sciencedaily.com/articles/a/antioxidant.htm

2. http://www.chiro.org/nutrition/Antioxidants.shtml

3. http://www.rice.edu/ jenky/sports/antiox.html

4. http://www.truestarhealth.com/Notes/2802005.html

5. http://voices.yahoo.com/what-free-radicals-why-theyharmful-7891348.html?cat=5

6. Freeman LR, Keller JN, Oxidative Stress And Cerebral Endothelial Cells : Regulation Of The Blood-brain-barrier And Antioxidant Based Interventions, Biochimica et Biophysica Acta, 2012, 1822, 822-829.

7. http://www.cenegenicspost.com/archives/Cenegenics\%20Car diovascular\%20ANTIOX\%20NOV.pdf

8. Pisoschi AM, Negulescu GP (2011) Methods For Total Antioxidant Activity determination: A Review, Biochem \& Anal Biochem, 1(1), 1-10.

9. http://farmacists.blogspot.in/2009/05/role-of-antioxidants-inbiological.html

10. http://en.wikipedia.org/wiki/Reactive_oxygen_species

11. http://chemwiki.ucdavis.edu/Biological_Chemistry/Vitamins, _Cofactors_and_Coenzymes/Vitamin_A

12. Jin H, Kanthasamy A, Ghosh A, Anantharam V, Kalyanaraman B, Kanthasamy AG, Mitochondria-targeted Antioxidants For Treatment Of Parkinson's Disease : Preclinical And Clinical Outcomes, Biochimica et Biophysica Acta, 2013, xxx, xxx-xxx

13. Lobo V, Patil A, Phatak A, Chandra N, Free Radicals, Antioxidants And Functional Foods : Impact On Human Health, Pharmacogn Rev, 2010, 4(8), 118-126.

14. Olazabal CN, Condori J, Olazabal LN, Medina-Boliver F, Differential Induction Of Antioxidants Stilbenoids In Hairy Roots Of Vitis rotundifolia Treated With Methyl jasmonate And Hydrogen Peroxide, Plant Physiology and Biochemistry, 2014, 74, 50-69.

15. http://en.wikipedia.org/wiki/Lutein

16. Laguerre M, Lecomte J, Villeneuve P, Evaluation Of The Ability Of Antioxidants To Counteract Lipid Oxidation : Existing Methods, New Trends And Challenges, Progress In Lipid Research, 2007, 46, 244-282.

17. http://www.seacoast.com/topic.php?health=glutathione+brand +name+india

18. http://www.igenericdrugs.com/?s=Glutathione

19. Gupta VK, Sharma SK, Plants As Natural Antioxidants, Natural Product Radiance, 2006, 5(4), 326-334.

20. https://www.academia.edu/939417/Medicinal_Properties_of_ Mango_Mangifera_indica

21. http://medicinalplantinindia.blogspot.in/2011/06/withaniasomnifera-ashwagandha-seeds.html

22. Javdan N, Estakhr J, In vitro Antioxidant Studies Of Various Extracts Of Salvia hypoleuca, Research Journal of Pharmacology, 2011, 5(6), 86-89.

23. Singh RP, Murthy KNC, Jayaprakasha GK, Studies On The Antioxidant Activity Of Pomegranate (Punica granatum) Peel And Seed Extracts Using In Vitro Models, Journal of Agricultural and Food Chemistry, 02/2002, 50(1), 81-6.

24. Padda MS, Phenolic Composition And Antioxidant Activity Of Sweet Potatoes [Ipomoea batatas (L.) Lam], A Dissertation Submitted To The Graduate Faculty Of The Louisiana State University and Agricultural And Mechanical College In Partial Fulfillment Of The Requirements For The Degree Of Doctor Of Philosophy In The Department Of Horticulture, May 2006, 1-98.

25. Deore SL, Khadabadi SS, Bhagure L, Ghorpade DS, In vitro Antimicrobial And Antioxidant Studies On Enicostemma axillare (Lam.) Raynal. Leaves, Natural Product Radiance, 2008, 7(5), 409-412.
26. Doshi GM, Shahare MD, Aggarwal GV, Pillai PG, Desai SK, Evaluation Of In-Vitro Antioxidant Methods Of Cassia auriculata, Dey Pharmacia Lettere, 2011, 3(3), 297-305.

27. Ali HFM, El-Beltagi HS, Nasr NF, Evaluation Of Antioxidant And Antimicrobial Activity Of Aloysia triphylla, Electronic Journal of Environmental, Agricultural and Food chemistry, 2011, 10(8), 2689-2699.

28. Rana MG, Katbamna RV, Padhya AA, Dudhrejiya AD, Jivani $\mathrm{NP}$, Sheth NR, In Vitro Antioxidant And Free Radical Scavenging Studies Of Alcoholic Extract Of Medicago Sativa L., ROM. J. BIOL. - PLANT BIOL, 2010, 55(1), 15-22.

29. Pawa RS, Jain A, Sharma P, Chaurasiya PK, Singour PK, In Vitro Studies On Sida cordifolia Linn. For Anthelmintic And Antioxidant Properties, Chinese Medicine, 2011, 2, 47-52.

30. Rong-zhen Z, Dao-wei Z, Oxidative Stress And Role Of Natural Plant Derived Antioxidants In Animal Reproduction, Journal of Integrative Agriculture, 2013, 12(10), 1826-1838

31. He K, Xuegang L, Xiaoli Y, Yuen L, Li X, Chen X et al, A Mitochondria-based Method For The Determination Of Antioxidant Activities Using 2', 7' - dichlorofluorescin diacetate Oxidation, Food Research International, 2012, 48, 454-461.

32. Laus MN, Tozzi D, Soccio M, Fratianni A, Panfili G, Pastore D, Dissection Of Antioxidant Activity Of Durum Wheat (Triticum durum Desf.) Grains As Evaluated By The New LOX/RNO Method, Journal of Cereal Science, (2012), 56, 214-222.

33. Bentayeb K, Vera P, Rubio C, Nerin C, The Additive Properties Of Oxygen Radical Absorbance Capacity (ORAC) Assay : The Case Of Essential Oils, Food Chemistry, (2014), 148, 204-208.

34. Qureshi MI, Abdin MZ, Ahmed J, Iqbal M, Effect Of Longterm Salinity On Cellular Antioxidants, Compatible Solute And Fatty Acid Profile Of Sweet Annie (Artemisia annua L.), Phytochemistry, 2013, 95, 215-223.

35. http://www.menshealth.com/nutrition/surprising-antioxidants

36. http://www.webmd.com/food-recipes/20-common-foodsmost-antioxidants

37. http://my.clevelandclinic.org/heart/prevention/nutrition/foodchoices/anti-oxidants.aspx

38. http://www.buzzle.com/articles/antioxidant-rich-foods-list-ofantioxidants-in-food.html

39. http://www.naturalnews.com/036992_antioxidants_best_sour ces_foods.html

40. Saleh MA, Clark S, Woodard B, Deolu-Sobogun SA, Antioxidant And Free Radical Scavenging Activities Of Essential Oils, Ethnicity \& Disease, 2010, 20, 78-82.

41. Kulisic T, Radonic A, Katalinic V, Milos M, Use Of Different Methods For Testing Antioxidative Activity Of Oregano Essential Oil, Food Chemistry, 2004, 85, 633-640.

42. Alam MN, Bristi NJ, Rafiquzzaman M, Review On In Vivo and In Vitro Methods Evaluation Of Antioxidant Activity, Saudi Pharmaceutical Journal, 2013, 21, 143-152.

43. Soobrattee MA, Neergheen VS, Luximon-Ramma A, Aruoma OI, Bahorun T, Phenolics As Potential Antioxidant Therapeutic Agents : Mechanism And Actions, Mutation Research, 2005, 579, 200-213.

44. Tai A, Sawano T, Yazama F, Ito H, Evaluation Of Antioxidant Activity Of Vanillin By Using Multiple Antioxidant Assays, Biochimica et Biophysica Acta, 2011, 1810, 170-177.

45. http://foodscience.cornell.edu/research/labs/liu/upload/08-11IFT-Food-Tech-lab-antioxidant-activity-assay.pdf

46. Lopez-Alarcon C, Denicola A, Evaluating The Antioxidant Capacity Of Natural Products : A Review On Chemical And Cellular-based Assays, Analytica Chimica Acta, 2013, 763, 110 